\title{
Effect of the initial stocking body weight on growth of spotted rose snapper Lutjanus guttatus (Steindachner, 1869) in marine floating cages
}

\author{
Efecto del peso inicial de cultivo sobre el crecimiento del pargo lunarejo Lutjanus guttatus \\ (Steindachner, 1869) en jaulas flotantes marinas \\ Sergio Castillo-Vargasmachuca ${ }^{1}$ Jesús T. Ponce-Palafox ${ }^{2,1}{ }_{\text {and Josesto Chávez Ortíz }}^{3}$
and Luis Arredondo-Figueroa ${ }^{4}$ \\ ${ }^{1}$ Universidad Autónoma de Nayarit-CBAP and CUVEDES. Ciudad de la Cultura Amado Nervo, C.P. 63000, Tepic, Nayarit, México \\ ${ }^{2}$ Universidad Autónoma del Estado de Morelos-CIB. Avenida Universidad 1001, CP 62209, Cuernavaca, México \\ ${ }^{3}$ Centro Interdisciplinario de Ciencias Marinas. Av. IPN s/n, Col. Playa Palo de Santa Rita, CP 23000, \\ La Paz, Baja California Sur, México \\ ${ }^{4}$ Universidad Autónoma Metropolitana Iztapalapa, Planta Experimental de Producción Acuícola, Departamento de Hidrobiología, \\ CBS, México. Av. San Rafael Atlixco 186, Colonia Vicentina Iztapalapa 0940, CP 09340, México DF \\ afjl@xanum.uam.mx
}

Resumen.- Pargos lunarejos con pesos promedio de 24,5 $\pm 3,7 \mathrm{~g}, 55,4 \pm 3,5 \mathrm{~g}$ y $110,2 \pm 4,6 \mathrm{~g}$ fueron introducidos para su engorde en jaulas flotantes de $100 \mathrm{~m}^{3}$ por un lapso de 153 días en Santa Cruz de Miramar, Nayarit, México, con la finalidad de encontrar el peso más adecuado de cultivo. Los pargos fueron alimentados dos veces al día con alimento comercial conteniendo 35 y $25 \%$ de proteína cruda durante el primero a tercer mes y en el cuarto y quinto mes respectivamente. Durante el experimento, la temperatura del agua varió de 25,6 a $32,3^{\circ} \mathrm{C}$. Al final del experimento se obtuvo una supervivencia que fluctuó de 67,5 a $74,7 \%$. Se determinaron, con base en el peso inicial, diferencias estadísticamente significativas $(P \leq 0,05)$ con respecto a la biomasa final cosechada. La máxima ganancia en peso promedio semanal fue de $12,8 \mathrm{~g}$ semana $^{-1}$ en los organismos con el mayor peso inicial (110,2 $\pm 4,6 \mathrm{~g})$. Esta información sugiere que la inclusión de pargos lunarejos con un peso de $110 \mathrm{~g}$ puede ser una buena estrategia para el engorde en jaulas flotantes.

Palabras clave: Pisces, Lutjanidae, cultivo en jaulas, acuicultura, supervivencia.

\begin{abstract}
Spotted rose snapper were stocked at body weight sizes of $24.5 \pm 3.7 \mathrm{~g}, 55.4 \pm 3.5 \mathrm{~g}$, and $110.2 \pm 4.6 \mathrm{~g}$ in three replicated marine floating cages of $100 \mathrm{~m}^{3}$ and reared for 153 days at Santa Cruz de Miramar in Nayarit, Mexico, to determine the appropriate stocking body weight size. Caged snapper were fed twice a day with commercial pellets containing 35\% crude protein during the first three months and $25 \%$ during the last two months, respectively. The water temperature of cages ranged from 25.6 to $32.3^{\circ} \mathrm{C}$. Mean survival ranged from 67.5 to $74.7 \%$. Stocking body weight sizes of snapper exerted significantly different $(P \leq 0.05)$ effects on the final biomass. The maximum mean weekly weight gain was $12.8 \mathrm{~g}$ week $^{-1}$ in cages with the $110.2 \pm 4.6 \mathrm{~g}$ body weight size. These results suggest, as a good strategy, the introduction of snappers with a total weight of $110 \mathrm{~g}$ for grow out in marine cages culture.
\end{abstract}

Key words: Pisces, Lutjanidae, cage culture, aquaculture, survival.

\section{Introduction}

Interest in cage culture in Latin American has been revived as an alternative crop for farmers outside traditional fish and shrimp farming areas. Species that have been researched and successfully reared in cages in the coastal plain of the American Pacific include species such as catfish, trout, tilapia, striped bass, red drum, bluegill sunfish, crappie, and carp. Due to its high potential in arid and tropical coastal regions, marine cage culture is now a strong alternative (Watanabe et al. 1990). Many marine species of high commercial value are now being reared in this 
condition, but the corresponding research has lagged behind other aquaculture research in recent years. On the other hand, future development of marine aquaculture in the Pacific Exclusive Economic Zone (EEZ) is constrained by legal, regulatory, and environmental impact concerns, which need to be addressed in order for the industry to become financially viable and internationally competitive (Rieser 1997). To promote regional productive activities in Latin American, it is necessary to look for alternatives, such as aquaculture of native species with low cost and minimum environmental impact. Nowadays, cage culture is receiving more attention by both researchers and commercial producers because of the decline in wild fish stocks. The spotted rose snapper, Lutjanus guttatus (Steindachner, 1869) is a good aquaculture candidate, since previous experiences in cage cultures in Mexico have shown that wild juvenile reach market sizes in less than a year (Aviles \& Mazon 1996). Studies have been carried out but focusing on spawning (Rojas 1997), fisheries (RojoVazquez et al. 1999, Chiappa-Carrara et al. 2004), and feeding habits (Rojas et al. 2004). However, the lack of knowledge about the growth of this species is evident. The objective of this study was to determine the effect of stocking body weight on the growth of spotted rose snapper, L. guttatus, in marine floating net cages in Miramar, Nayarit, Mexico.

\section{Material and methods}

\section{Juvenile source}

The experiment was carried out during five months (from May to October). Spotted rose snapper were captured in front of Platanitos, Nayarit. The collection operations of juvenile and sub-adults were carried out from January 25 to March 26, 2004. In periods of 30 minutes haulage at a speed of 2.1 knots with two "semiportuguesas" nets of $24 \mathrm{~m}$ in length to a depth average of $27 \mathrm{~m}$, haulage of nets was carried out slowly. Fishes were transported in six 1000-L plastic tanks with constant aeration, and acclimated for 48 to 72 hours before being introduced in cages.

\section{Experimental design}

The study was conducted in "Punta el Caballo" Santa Cruz de Miramar, Nayarit. The farm is located offshore at $300 \mathrm{~m}$ from the Santa Cruz de Miramar town (478.214 E, $2370000 \mathrm{~N} ; 478.514$ E, $2370000 \mathrm{~N}$; 478.514 E, $2369800 \mathrm{~N} ; 478.214$ E, $2369800 \mathrm{~N})$. The farm complex comprises 10 cages $(5 \times 5 \times 4 \mathrm{~m})$. The cages were placed above a sandy bottom in 12 to $15 \mathrm{~m}$ of water. Floating net cages were made of nylon-tarred polyamide and the structure was set using six 200-L floating tanks and $50 \mathrm{~L}$ glass tanks. The experimental design comprised three stocking body weight sizes: SJ $=$ small juvenile; $\mathrm{J}=$ juvenile, and $\mathrm{SA}=$ sub-adults, and were carried out in three replicates each, using nine marine floating cages with $100 \mathrm{~m}^{3}$ in a randomized design to facilitate analysis. Table 1 shows the initial stocking data. A total of 10773 fish were stocked in nine cages. The experiment lasted 153 days.

Snappers were fed twice a day at 8:00 and 16:00 h, with commercially formulated feed (Aquaprofile, Purina) containing 35\% crude protein and $7 \%$ of lipids, during the first three months, and $25 \%$ of crude protein and $7 \%$ of lipids, during the last two months. Feed was provided at a rate of $1.5 \%$ body weight day $^{-1}$, during the first three months; thereafter, the feeding rate was reduced to $1.2 \%$ body weight day $^{-1}$ based on the monthly weight of fishes.

Table 1

Initial stocking density of spotted rose snapper (L. guttatus) culture at different stocking body weights in marine cages over 153 days

Densidad inicial de siembra del pargo lunarejo (L.guttatus) cultivado con diferentes pesos, en jaulas marinas por un periodo de 153 días

\begin{tabular}{|c|c|c|c|c|}
\hline *Treatment & Fishes & $\begin{array}{c}\text { Mean initial body length } \\
(\mathrm{cm})\end{array}$ & $\begin{array}{c}\text { Mean initial body weight } \\
\text { (g) }\end{array}$ & $\begin{array}{c}\text { Initial density } \\
\left(\mathrm{kg} \mathrm{m}^{-3}\right)\end{array}$ \\
\hline SJ & 1,203 & 10.6 & 24.5 & 0.295 \\
\hline $\mathbf{J}$ & 1,189 & 14.6 & 55.4 & 0.659 \\
\hline SA & 1,199 & 18.1 & 110.2 & 1.321 \\
\hline
\end{tabular}

$* \mathrm{SJ}=$ small juvenile; $\mathrm{J}=$ juvenile and $\mathrm{SA}=$ sub-adults 


\section{Water quality}

Water samples were taken every day in each cage at about 10:00 $\mathrm{h}$ for temperature and dissolved oxygen analyses, using a thermometer and a YSI model 54 oxygen meter; $\mathrm{pH}$ was measured with a $\mathrm{pH}$ meter (Orion) and transparency with a Secchi disk. The ammonia nitrogen content of water in each cage was determined using a YSI model 9000 photometer.

\section{Growth and survival of fish}

Individual length $(\mathrm{cm})$ and wet weight $(\mathrm{g})$ were determined at the beginning of the experiment and every four weeks during the 153 days. Prior to weighing, fish were placed on absorbent paper to remove excess water. Specific growth rate (SGR, \% body weight/d) was calculated using the formula SGR $=100 \mathrm{X}(\mathrm{Ln} \mathrm{Wf}-\mathrm{Ln} \mathrm{Wi}) / \mathrm{t}$, where $\mathrm{Wf}=$ mean weight at the end of the culture period, $\mathrm{Wi}=$ mean weight at the beginning of the experiment, and $t=$ time in days of the experimental period (Ricker 1979). Mean daily weight gain (MDWG, g/week) was calculated from $\mathrm{MDWG}=(\mathrm{Wf}-\mathrm{Wi}) / \mathrm{t}$. The food conversion ratio (FCR) was obtained from FCR $=\mathrm{g}$ feed consumed $/ \mathrm{g}$ wet weight gained (Al Hafedh et al. 1999). Final survival per treatment was also recorded.

\section{Statistical analysis}

Statistical analysis was carried out according to Montgomery (1984). To determine whether significant differences existed between the different treatments and the parameters tested, all results were analyzed using a one-way variance analysis (ANOVA) and Tuckey's multiple comparison of means. Statistical analysis was performed on data after arcsine transformations. Probabilities of $P \leq 0.05$ were considered significant.

\section{Results}

\section{Water quality}

There were no significant differences $(P \geq 0.05)$ in water quality parameters among treatments during the experimental period. Water temperature ranged from 25.6 to $32.3^{\circ} \mathrm{C}$; after 30 days of culture, the temperature increased 3 to $4^{\circ} \mathrm{C}$. Water temperature ranged from 30 to $32^{\circ} \mathrm{C}$ during most of the culture. The dissolved oxygen (DO) fluctuated between 4.2 and $6.2 \mathrm{mg} \mathrm{L}^{-1}$. At the beginning of the culture, the concentration of DO was higher $\left(6.2 \mathrm{mg} \mathrm{L}^{-1}\right)$; Secchi disk visibility varied from 0.6 to $8 \mathrm{~m}$. During the first 75 days of culture, the
Secchi disk value was lower $(1 \mathrm{~m})$. Ammonia-nitrogen fluctuated from 0.016 to $1.18 \mathrm{mg} \mathrm{L}^{-1}$ throughout the experimental period, the highest concentrations of ammonia were registered during the first 100 days of cultivation, later on, and they decreased to $0.01 \mathrm{mg} \mathrm{L}^{-1}$ (Fig. 1).

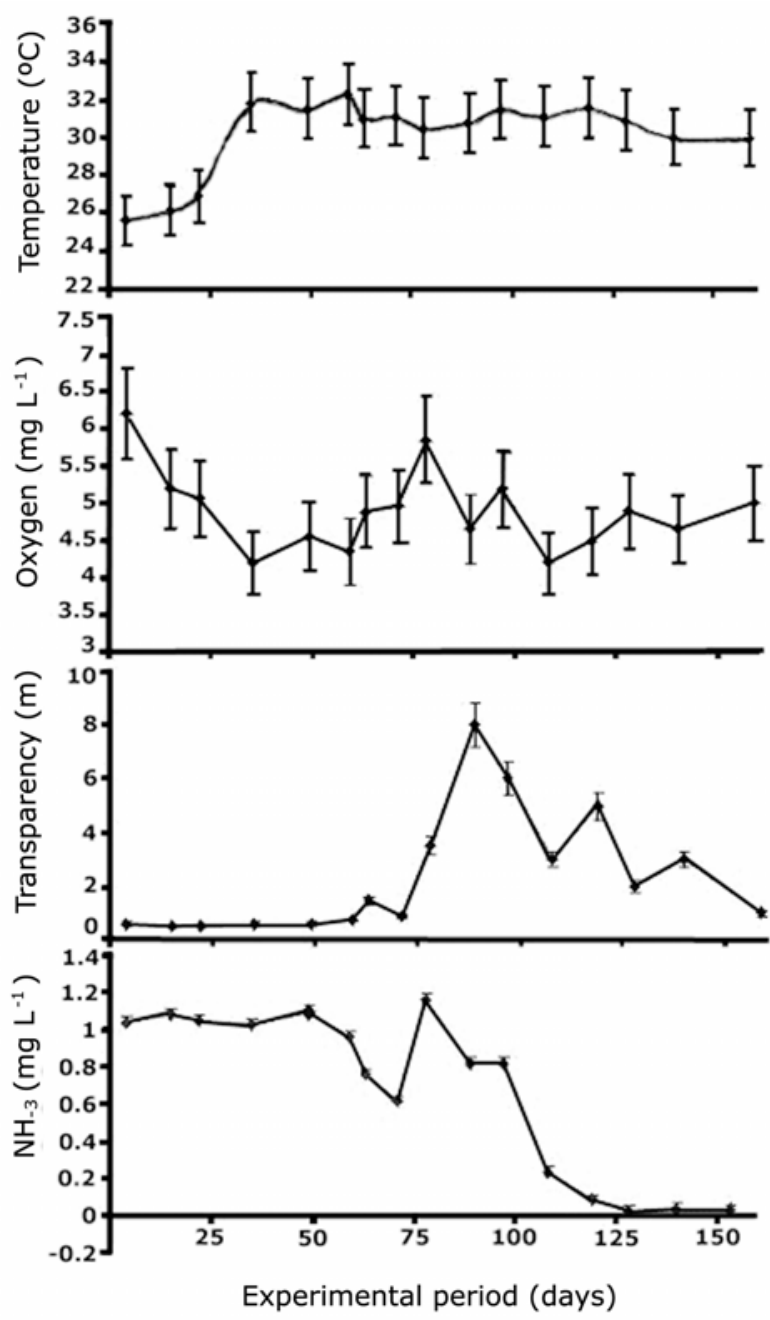

Figure 1

Fluctuation of water temperature, dissolved oxygen, transparency, and ammonia at 10:00 $\mathrm{h}$ during the experimental period

Fluctuaciones de la temperatura, oxígeno disuelto, transparencia y amoniaco del agua, a la 10:00 horas, durante el periodo experimental 


\section{Growth and survival of fish}

Small juvenile fishes grew from an average weight of $24.5 \mathrm{~g}$ to $155.2 \mathrm{~g}$ in $153 \mathrm{~d}$; MWWG was of $0.93 \mathrm{~g} \mathrm{~d}^{-1}$ and specific growth rate (SGR) reached $1.2 \% \mathrm{~d}^{-1}$, and the Food Conversion Ratio (FCR) was 2.0. Juvenile fishes grew from an average weight of $55.4 \mathrm{~g}$ to 226.2 g. MWWG was of $1.21 \mathrm{~g} \mathrm{~d}^{-1}$, SGR of $1.1 \% \mathrm{~d}^{-1}$, and FCR was 1.8. Subadults fishes grew from an average weight of $110.2 \mathrm{~g}$ to $366.1 \mathrm{~g}$. MWWG was $1.83 \mathrm{~g} \mathrm{~d}^{-1}$, SGR was $1.0 \% \mathrm{~d}^{-1}$, and FCR was 1.9. After 61 days of culture, the weight average of the subadults was significantly different $(P \leq 0.05)$ from that of juvenile (Fig. 2). The average weight of small juvenile and juvenile was significantly different $(P \leq 0.05)$ at the end of the culture period compared with the initial weight. Significant differences $(P \leq 0.05)$ were observed in the mean final body length, mean final body weight, final biomass, and mean weekly weight gain in the three stocking sizes.

The stocking body weight affected the average final body weight and the mean weekly weight gain. These gains were significantly higher $(P \leq 0.05)$ in sub-adults (mean initial body weight $110 \mathrm{~g}$ ) compared to small juvenile (24.5 g) and juvenile (55.4 g). No significant difference $(P \geq 0.05)$ was found among the three treatments in the feed conversion ratio (FCR), specific growth rate (SGR), and survival (Table 2 and Fig. 2). It was found that subadults had a higher survival although not statistically significant.

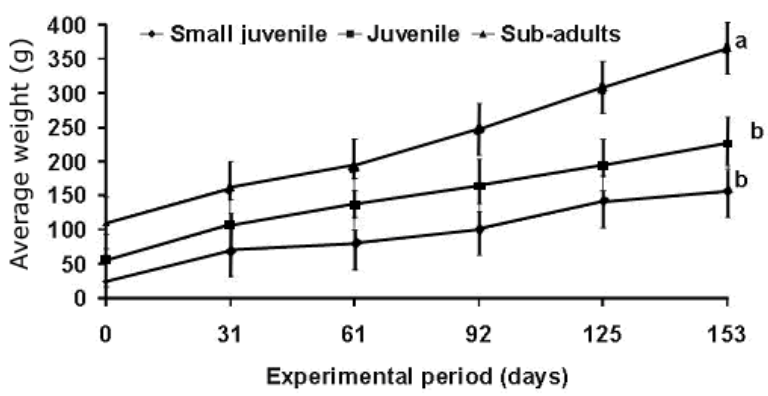

Figure 2

Growth rate of spotted rose snapper (L. guttatus), cultured in different stocking body sizes in marine floating cages in a period of 153 days

Tasa de crecimiento del pargo lunarejo (L. guttatus), cultivado en diferentes tallas en jaulas marinas flotantes en un periodo de 153 días

Table 2

\section{Growth performance of spotted rose snapper (L. guttatus) culture at different stocking body sizes in marine cage over 153 days}

Indicadores de crecimiento del pargo lunarejo (L. guttatus) cultivado con diferentes tallas, en jaulas marinas durante 153 días

\begin{tabular}{lccc}
\hline \multicolumn{1}{c}{ Parameter/*Treatment } & SJ & J & SA \\
\hline Mean initial body length $(\mathrm{cm})$ & $10.6 \pm 2.1^{\mathrm{a}}$ & $14.6 \pm 1.3^{\mathrm{a}}$ & $18.1 \pm 1.2^{\mathrm{b}}$ \\
Mean final body length $(\mathrm{cm})$ & $22.51 \pm 2.2^{\mathrm{a}}$ & $24.65 \pm 1.1^{\mathrm{a}}$ & $29.53 \pm 1.5^{\mathrm{b}}$ \\
Mean initial body weight $(\mathrm{g})$ & $24.5 \pm 3.7^{\mathrm{a}}$ & $55.4 \pm 3.5^{\mathrm{b}}$ & $110.2 \pm 4.6^{\mathrm{c}}$ \\
Mean final body weight $(\mathrm{g})$ & $155.2 \pm 7.8^{\mathrm{a}}$ & $226.2 \pm 6.9^{\mathrm{b}}$ & $366.1 \pm 8.2^{\mathrm{c}}$ \\
Density (fish cage $\left.{ }^{-1}\right)$ & $1,203^{\mathrm{a}}$ & $1,189^{\mathrm{a}}$ & $1,199^{\mathrm{a}}$ \\
Final Biomass $(\mathrm{kg})$ & $126^{\mathrm{a}}$ & $194^{\mathrm{b}}$ & $325^{\mathrm{c}}$ \\
Mean weekly weight gain $\left(\mathrm{g} \mathrm{eek}^{-1}\right)$ & $6.5^{\mathrm{a}}$ & $8.5^{\mathrm{b}}$ & $12.8^{\mathrm{c}}$ \\
Specific growth rate $\left(\% \mathrm{~d}^{-1}\right)$ & $1.2^{\mathrm{a}}$ & $1.1^{\mathrm{a}}$ & $1.0^{\mathrm{a}}$ \\
Feed Conversion ratio (FCR) & $2.0^{\mathrm{a}}$ & $1.8^{\mathrm{a}}$ & $1.9^{\mathrm{a}}$ \\
Survival (\%) & $67.5^{\mathrm{a}}$ & $71.5^{\mathrm{a}}$ & $74.7^{\mathrm{a}}$ \\
\hline
\end{tabular}

*SJ $=$ Small Juvenile; $\mathrm{J}=$ Juvenile; $\mathrm{SA}=$ Sub-adults

Different superscripts $(\mathrm{a}-\mathrm{c})$ in rows indicate significant differences $(P>0.05)$ 


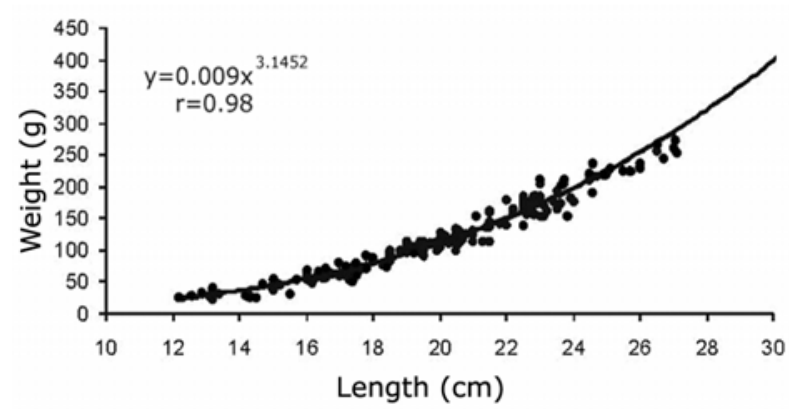

Figure 3

Length-weight relationship of spotted rose snapper $(L$. guttatus) cultured at different stocking body sizes in marine floating cages in a period of 153 days

Relación longitud-peso del pargo lunarejo (L. guttatus) cultivado en diferentes tallas en jaulas marinas flotantes en un periodo de 153 días

The length-weight relationship was determined through the following equation: $\mathrm{Wt}=0.009 * \mathrm{Lt}^{3.1452}$ (Fig. 3). This equation corresponds to: $\mathrm{Ln} \mathrm{W}=-4.71+$ $3.1452 *$ Ln L $(r=0.98)$. The values relate to the wellbeing index associated to the individuals with highest weights for a given length. The highest $b$ values indicate the inflection of the curve for the asymptotic values, indicating an allometric growth, that is, the length becomes an irrelevant variable in relation to the weight. The length-weight relationship follows the cube law during the experimental period.

\section{Discussion}

Results show that after 153 rearing days, small juvenile, juvenile, and subadults exhibited statistically significant differences $(P \geq 0.05)$ in final body length, final body weight, final biomass, and mean weekly weight gain. Juvenile exhibited a uniform growth, whereas subadults exhibited a faster growth rate. Pozo (1979) calculated the length-weight relationship exponent (b) of wild mutton snapper (Lutjanus analis) to be of 2.53 for males and 2.59 for females. Results of grow out trials reported for this species in floating cages demonstrated length-weight exponent values of 3.11 and 3.22 in high and low-density stocked cages, respectively, a similar exponent (b) to that calculated in this work of 3.14 for L. guttatus. During $80 \%$ of the cultivation time, water temperature was up to $30^{\circ} \mathrm{C}$, and did not present any apparent effects on the growth rate of snappers. Although, dissolved oxygen reached values of $2 \mathrm{mg} \mathrm{L}^{-1}$, transparency of $7.4 \mathrm{~m}$ with the
Secchi disk, and ammonium reached $1.16 \mathrm{mg} \mathrm{L}^{-1}$, no negative effects on the growth and survival rates of the organisms were observed. This agrees with other experiments performed in snappers by Benetti et al. (2002), who found in marine cages culture high variations of water quality parameters.

Information of growth bioindicators, at different densities, stocking body weight size, and feeding rates are essential to understand better their effects on snappers in marine cages culture. The growth and food conversion rates were similar in the three treatments, in spite of the differences of the initial wet weight. In our study, stocking body weight affected weekly weight gain in L. gutattus (Table 2), suggesting that higher stocking body weights ( $>100 \mathrm{~g})$ can be used in marine cages culture. Research on the influence of stocking body weight on growth and production for other fish has been made in catfish (Chapman 2000) and goldfish (Stone \& McNulty 2003). The higher initial cost for larger fingerlings, juvenile, and sub-adults are costeffective than smaller fingerlings or juvenile.

Although stocking densities of over $15 \mathrm{~kg} \mathrm{~m}^{-3}$ are common in cage culture of other fish species, such as yellowtail hamachi Seriola quinqueradiata (Aoki 1995, Nakada 2000), red sea bream (Ikenoue \& Kafuku 1992), gilthead sea bream (Kissil et al. 2000b), sea bass (Kissil et al. 2000a), salmonids (Roberts \& Hardy 2000), and the Japanese flounder (Min 1995), for experimental studies on growth, initial stocking densities of 5 and 25 fingerlings $\mathrm{m}^{-3}$ have been used for snappers (Benetti et al. 2002) and those used in this work (1.26 to 3.24 fingerlings $\left.\mathrm{m}^{-3}\right)$. These lower stocking densities, however, were sufficient to prove the technical viability of rearing spotted rose snapper in cages.

The increases in the average weight of fish in this study were considerably higher in subadults than in small juvenile and juvenile. These data suggest that stocking spotted rose snapper in cages at body weights of around $100 \mathrm{~g}$ can be a good strategy, considering the FCR, good growth indicators, high economic return, and achieving commercial sizes in less time (Olivares $\&$ Boza 1999). The dry pellets containing 35-25\% crude protein and $7 \%$ crude fat used for feeding spotted rose snappers during these grow out trials performed satisfactorily in terms of growth and FCR. This agrees with observations made in cage culture of yellowtail, mackerel, mutton snapper, which exhibited good 
growth rates when fed formulated feeds (Watanabe et al. 1991, Juell et al. 1998, Benetti et al. 2002).

The survivals obtained in this work (67.5 to $74.7 \%$ ) are similar to those calculated for L. guttatus by Aviles \& Mazon (1996) in experimental tests (65 to $75 \%$ ) in floating cages. The overall survival rate of $70 \%$ can be considered satisfactory (Benetti et al. 2002). Most of the mortality occurred immediately following the stocking of the first 10,773 fingerlings in the cages and can be attributed to handling stress. Throughout the experimental trials, the spotted rose snapper proved to be a hardy fish, resistant to diseases, and tolerant to a wide range of environmental parameters, as shown in Fig. 1.

The supply of seed to farms, however, is dependent on wild fry, which is limited, seasonal and unreliable, therefore, constituting a major constraint in the sustainability of its culture. Consequently, it is recommended that attempts be made to develop a reliable breeding technique to ensure consistent fry supply to support spotted rose snapper aquaculture in the region.

\section{Literature cited}

Al-Hafedh YS, AQ Siddiqui \& MY Saiady. 1999. Effects of dietary protein levels on gonad maturation, size and age at first maturity, fecundity and growth of Nile tilapia. Aquaculture International 7: 319-332.

Aoki H. 1995. Review of the nursery and growout culture techniques for yellowtail (Seriola quinqueradiata) in Japan. In: Main KL \& C Rosenfeld (eds), Culture of highvalue marine finfish in Asia and the United States. Workshop Proceedings, 8-12 August 1994, Honolulu, Hawaii, USA, pp. 47-55. The Oceanic Institute, Honolulu.

Aviles AQ \& JM Mazon. 1996. Estado actual y perspectivas del cultivo de peces marinos en México. Acuicultura en Latinoamérica, IX Congreso Latinoamericano de Acuicultura, pp. 90-100. Universidad Católica del Norte, Coquimbo.

Benetti DD, JA Mattera, OM Stevens, JF Alarcon, MW Feeley, FJ Rotman, Y Minemoto, G Banner-Stevens, J Fanke, S Zimmerman \& L Eldridge. 2002. Growth, survival, and feed conversion rates of hatchery-reared mutton snapper Lutjanus analis cultured in floating net cages. Journal of the World Aquaculture Society 33(3): 349-357.
Chapman FA. 2000. Farm-raised channel catfish. Circular University of Florida /IFAS 1052: 1-4.

Chiappa-Carrara X, A Rojas-Herrera \& M Mascaró. 2004. Coexistencia de Lutjanus peru y Lutjanus guttatus (Pisces: Lutjanidae) en la Costa de Guerrero, México: relación con la variación temporal en el reclutamiento. Revista de Biología Tropical 52(1): 177-185.

Ikenoue H \& $\mathbf{T}$ Kafuku. 1992. Modern methods of aquaculture in Japan, 274 pp. Elsevier, Amsterdam.

Juell J-E, JC Holm, GI Hemre \& O Lie. 1998. Growth and feeding behaviour of caged Atlantic mackerel, Scomber scombrus L. Aquaculture Research 29:115-122

Kissil GW, A Tandler, A Colorni \& A Elizur. 2000a. Sea bass culture. In: Stickney R (ed), Encyclopedia of Aquaculture, pp. 778-784. John Wiley \& Sons, Inc., New York.

Kissil GW, A Tandler A Elizur, A Colorni \& Y Zohar. 2000b. Gilthead sea bream culture. In: Stickney R (ed), Encyclopedia of Aquaculture, pp. 408-416. John Wiley \& Sons, New York.

Min BS. 1995. A review of the nursery and growout culture techniques for flounder (Paralichthys olivaceus) in Korea. In: Main KL \& C Rosenfeld (eds), Culture of high-value marine finfish in Asia and the United States. Workshop Proceedings, 8-12 August 1994, Honolulu, Hawaii, USA,pp. 147-152. The Oceanic Institute, Honolulu.

Montgomery DC. 1984. Design and analysis of experiments, 660 pp. John Wiley \& Sons, New York.

Nakada M. 2000. Yellowtail and related species culture. In: Stickney R (ed), Encyclopedia of Aquaculture, pp.10071005. John Wiley \& Sons, New York.

Olivares O \& J Boza. 1999. Crecimiento de juvenile de pargo mancha (Lutjanus guttatus) utilizando alimento granulado en condiciones de laboratorio. Uniciencia 1516: $45-48$.

Pozo E. 1979. Edad y crecimiento del pargo criollo (Lutjanus analis Cuvier, 1828) en la plataforma nororiental de Cuba. Revista Cubana de Investigación Pesquera 4(2): 124.

Ricker WE. 1979. Growth rates and models. In: Hoar WS, DJ Randall \& JR Brett (eds), Fish Physiology. VIII. Bioenergetics and growth, pp. 677-743. Academic Press, New York.

Rieser A. 1997. Defining the federal role in offshore aquaculture: should it feature delegation to the states? Ocean and Coastal Law Journal 2: 209-234. 
Roberts RJ \& RW Hardy. 2000. Salmon culture. In: Stickney R (ed), Encyclopedia of Aquaculture, pp. 773778. John Wiley \& Sons, New York.

Rojas JR. 1997. Fecundidad y épocas de reproducción del pargo mancha Lutjanus guttatus (Pisces: Lutjanidae) en el Golfo de Nicoya, Costa Rica. Revista de Biología Tropical 44 (3)/45 (1): 477-487.

Rojas JR, E Maravilla \& F Chicas. 2004. Hábitos alimentarios del pargo mancha Lutjanus guttatus (Pisces: Lutjanidae) en Los Cóbanos y Puerto La Libertad, El Salvador. Revista de Biología Tropical 52(1): 163-170.

Rojo-Vázquez JA, F Arreguín-Sánchez, E GodínezDomínguez \& M Ramírez-Rodríguez. 1999. Gillnet selectivity for the spotted rose snapper (Lutjanus guttatus) and the amarillo snapper (Lutjanus argentiventris) in Navidad Bay, Jalisco, México. Ciencias Marinas 25(1): $145-152$.

Stone N \& E McNulty. 2003. The effect of stocking and feeding rates on growth and production of feeder goldfish in North American. Journal of Aquaculture 65: 82-90.

Watanabe WO, JH Clark \& JB Dunham. 1990. Culture of Florida red tilapia in marine cages: the effects of stocking density and dietary protein on growth. Aquaculture 90: 311-321.

Watanabe T, H Sakamoto, M Abiru \& J Yamashita. 1991. Development of a new type of dry pellet for yellowtail. Nippon Suisan Gakkaishi 57: 891-897.

Recibido el 6 de noviembre de 2006 y aceptado el 28 de julio de 2007 